\title{
MONITORING OF TOXIC METALS (CADMIUM, LEAD, ARSENIC AND MERCURY) IN VEGETABLES OF SINDH, PAKISTAN
}

\author{
${ }^{1}$ Muhammad Abbas, ${ }^{2}$ Zahida Parveen, ${ }^{2}$ Muhammad Iqbal, ${ }^{1}$ Riazuddin, ${ }^{1}$ Sajid Iqbal, ${ }^{1}$ Mubarik \\ Ahmed, ${ }^{3}$ Rashid Bhutto* \\ ${ }^{1}$ Grain Quality Testing Laboratories, Karachi, Pakistan \\ ${ }^{2}$ Pesticide Research Institute Southern-Zone Agricultural Center, Pakistan Agricultural Research \\ Council, Karachi University Campus, Old Block No.9 and 10, Karachi-75270, Pakistan \\ ${ }^{3}$ Department of Plant Breeding and Genetics, Sindh Agriculture University, Tandujam, Hydrabad \\ *Corresponding author: bhutto_agricultural_2004@yahoo.com \\ Received 9 March, 2010; Revised 14 July, 2010
}

\begin{abstract}
A monitoring study was carried out with the aim to assess the level of toxic metals i.e., lead $(\mathrm{Pb})$, cadmium $(\mathrm{Cd})$, arsenic (As) and mercury $(\mathrm{Hg})$ in different vegetables grown in Sindh province of Pakistan during 2007-2008. Two hundred ten samples of twenty one vegetables were collected from farmers' field of Sindh and exporters at Karachi. These samples were grouped into four categories viz., leafy, root and tuberous, cucurbits and fruity. The samples in duplicate were digested with nitric and perchloric acid mixture with 3:1 ratio. Cadmium and $\mathrm{Pb}$ were analyzed with Graphite Furnace Atomic Absorption Spectrophotometer and $\mathrm{As}$ and $\mathrm{Hg}$ on Atomic Absorption using Vapor and Hydride Generation Assembly. Average concentration of $\mathrm{Cd}, \mathrm{Pb}, \mathrm{As}$ and $\mathrm{Hg}$ in leafy vegetables was found $0.083 \mu \mathrm{gg}^{-1}, 0.05 \mu \mathrm{gg}^{-1}, 0.042 \mu \mathrm{gg}^{-1}$ and $0.008 \mu \mathrm{gg}^{-1}$ respectively, in roots and tuberous vegetables was $0.057 \mu \mathrm{gg}^{-1}, 0.03 \mu \mathrm{gg}^{-1}, 0.045 \mu \mathrm{gg}^{-1} \& 0.004$ $\mu \mathrm{gg}^{-1}$ respectively, in cucurbit vegetables was $0.021 \mu \mathrm{gg}^{-1}, 0.051 \mu \mathrm{gg}^{-1}, 0.056 \mathrm{ggg}^{-1}$ and 0.0089 $\mu \mathrm{gg}^{-1}$ respectively and in fruity vegetables was $0.035 \mu \mathrm{gg}^{-1}, 0.067 \mu \mathrm{gg}^{-1}, 0.054 \mu \mathrm{gg}^{-1}$ and 0.007 $\mu \mathrm{gg}^{-1}$ respectively. In leafy vegetables, the concentration of cadmium, lead and mercury were found comparatively higher than other three groups of vegetables. However, concentration of heavy metals found in the samples of all four categories of vegetables, was within the permissible limits and safe to consume.
\end{abstract}

Keywords: Atomic Absorption Spectroscopy, Heavy Metals, Vegetables, Graphite Furnace, Vapor Generation and Hydride Generation

\section{INTRODUCTION}

Agriculture is a complex phenomenon and exerts both favorable and unfavorable consequences on environment (Ghandi, 2000). In Pakistan, agriculture is the mainstay of national economy. The sector receives second priority after defense. Its share in GDP is about $24 \%$. It contributes $35 \%$ to the export earnings and employs $51 \%$ of total labor force and play vital role in uplifting the life of $70 \%$ of rural population. Besides, major crops of Pakistan, vegetables are grown widely sufficient quantities of some vegetables such as chili, tomato etc. are exported to various countries. In Pakistan, share of vegetable export is about 0.22\% (Government of Pakistan 2008-09). 
Soil and environmental pollution is a matter of great concern and has been accepted as a global problem because of its adverse effect on human health, plants, animals and all exposed material to $\mathrm{Cd}, \mathrm{Pb}$, As and $\mathrm{Hg}$ (Irshad et al. 1997). Heavy metal toxicity has received special attention globally due to neurotoxin, carcinogenic and several other impacts arising from their consumption even at lower contents. (Sathawara, et al., 2004). Prolonged accumulation of heavy metals through food stuff may lead to chronic effect in the kidney and liver of humans and causes disruption of numerous biochemical processes leading to cardiovascular, nervous, kidney and bone diseases (Jarup, 2003). Modern analytical techniques and ultra sensitive instruments analyzing metal contents even at ppb levels have recently resolved several health disorders associated with intake of toxic metals. Recent developments in toxicities and other disorders resulting from ingestion of toxic metals have compelled food regulators around the world to revise the safe limits of these toxicants to ensure consumer health.

Soil eco-system throughout world has been contaminated with heavy metals by various human activities and movement of metals in food chain has become human health hazard (Zahir et al., 2009). Land contamination with heavy metals is increasing and becoming environmental, economic and planning issue in Pakistan (Bhutto et al., 2009).

Soil chemical composition plays important role in composition of plant materials. Overall toxic metal availability in soil rhizosphere contributes to metal contents in fruits/ vegetables. Anthropogenic activity such as application of fertilizers, manures also affect soil metal content (e.g. phosphatic fertilizers being main source of $\mathrm{Cd}$ impurity). Soils in Pakistan contain $\mathrm{Pb}$ and $\mathrm{Cd}$ at sufficient levels (Ahmed et al., 1994). Perveen et al. (2003) reported the presence of $\mathrm{Cd}$ and $\mathrm{Pb}$ concentration of $0.08 \mu \mathrm{gg}^{-1}$ and $0.12{\mu \mathrm{gg}^{-1}}$ respectively toxic metals at lower concentration. Sharma et al. (2009) also reported $\mathrm{Cd}, \mathrm{Pb}$ and $\mathrm{As}$ at $0.6 \mu \mathrm{gg}^{-1}, 0.15 \mu \mathrm{gg}^{-1}$ and $0.008 \mu \mathrm{gg}^{-1}$ respectively in leafy and fruity vegetables. Leafy vegetables accumulate much higher contents of heavy metals as compare to other vegetables because leafy vegetables are most exposed to environmental pollution because of large surface area (Itanna et al., 2002). Considering the significance of these metals and food consumption patterns, a detailed study was carried out to monitor levels of lead, cadmium, arsenic and mercury in different vegetables grown in the province of Sindh. The aim of this study was to monitor the toxic heavy metals $\mathrm{Cd}, \mathrm{Pb}, \mathrm{As}$ and $\mathrm{Hg}$ in vegetables.

\section{MATERIALS AND METHODS}

Two hundred ten (210) samples of vegetables i.e. leafy vegetables (Coriander, Methi, Spinach and Mint), root and tuberous vegetables (Arum, Onion, Potato, Radish, Sugar Beet and Turnip), cucurbit vegetables (Bitter Gourd, Cucumber, Indian Squash and Pumpkin) and fruity vegetables (Brinjal, Cabbage, Cauliflower, Chilies, French Beans, Okra and Tomato) were collected from farmers' field of Khairpur, Sukkur, Hydrabad and Karachi district and from exporters of Karachi. Samples were placed in polyethylene bags and brought to laboratory for analysis. All samples were washed with tape water followed with DDI (double de-ionized distil water). Samples were cut in into small pieces and dried at $105^{\circ} \mathrm{C}$ for 18 hours (Wiermans et al., 1986). After drying the samples were ground into powder form. Approximately $1.0 \mathrm{~g}$ of each sample in duplicate taken into digestion tubes, were soaked in 40ml of nitric acid and perchloric acid (3:1) and left overnight for complete contact of material. Next day, samples were digested first at $120^{\circ} \mathrm{C}$ for 2 hrs and then $180^{\circ} \mathrm{C}$ on heating digester (VELP Scientifica) till the solution becomes transparent. Digestion stopped when sample solution reduced to 2-3 ml. Cooled samples were transferred into 
$100 \mathrm{ml}$ volumetric flask and volume raised up to the mark with $0.1 \mathrm{M} \mathrm{HNO}_{3}$ (AOAC 2000). All glasswares including digestion tubes were soaked with $30 \% \mathrm{HNO}_{3}$ for 8 hours and finally washed with DDI water (Robert et al., 1987). Following the instruction of Instrument operational manual provided by manufacturer, analysis of $\mathrm{Cd}, \mathrm{Pb}$, $\mathrm{As}$ and $\mathrm{Hg}$ was carried out using Atomic Absorption Spectrophotometer coupled with Graphite Furnace and Vapor and Hydride generation assembly. Cadmium and $\mathrm{Pb}$ was analyzed on Graphite Furnace Atomic Absorption Spectrophotometer and As and $\mathrm{Hg}$ on Atomic Absorption using Vapor and Hydride Generation Assembly.

\section{RESULTS AND DISCUSSION}

Heavy metals are of great significance in ecochemistry and ecotoxicology because of their toxicity at low levels and tendency to accumulate in human organs (Viqar et al 1992). The results obtained are given in Table 2 to 4 . The dietary limit in food and food stuff for cadmium is 0.1 $\mu \mathrm{gg}^{-1}$ (Table 1). High concentration of cadmium exerts detrimental effects on human health and causes severe diseases such as tubular growth, kidney damage, cancer, diarrhea and incurable vomiting. Results of the study (Table 2 to 4 ) show that among the four groups of vegetables, the maximum concentration $\left(0.09 \mu^{-1}\right)$ of cadmium was found in leafy vegetables (fenugreek/ methi) whereas the minimum concentration $\left(0.002 \mu \mathrm{gg}^{-1}\right)$ was in cucurbit vegetables (Indian squash). Nergus et al. (2005) also reported high concentration $\left(2.5 \mu^{-1}\right)$ in fenugreek/ methi). The concentration of lead if exceeding the maximum permissible limits $\left(0.2 \mu \mathrm{gg}^{-1}\right)$ in human, affect nervous system, bones, liver, pancreases, teeth and gum \& causes blood diseases. Results of our study show that maximum concentration $\left(0.15 \mu \mathrm{gg}^{-1}\right)$ of lead was found in leafy vegetables (coriander) and the minimum concentration $\left(0.001 \mathrm{\mu gg}^{-1}\right)$ in root/ tuberous vegetables (sugar beet). Parveen et al (2003) also reported the similar trend of lead distribution in vegetables.

Mercury is more toxic than $\mathrm{Cd}$ and $\mathrm{Pb}$. The concentration of mercury exceeding the maximum permissible limit $\left(0.03 \mu \mathrm{gg}^{-1}\right)$ in food and food stuff cause serious health problems such as loss of vision, hearing and metal retardation and finally death occurs. This study show that the maximum concentration $\left(0.02 \mathrm{\mu gg}^{-1}\right)$ of mercury was found in leafy vegetables (fenugreek/ methi) and the lower concentration $\left(0.001 \mathrm{\mu gg}^{-1}\right)$ was found in root/ tuberous vegetables (potato and turnip).

Arsenic is extremely toxic. The concentration of arsenic exceeding the maximum permissible limit $\left(0.03 \mathrm{\mu gg}^{-1}\right)$ in foodstuff cause short term (nausea, vomiting, diarrhea, weakness, loss of appetite, cough and headache) and long term (cardiovascular diseases, diabetes and vascular diseases) health effects. Results show that the maximum concentration $\left(0.083 \mu \mathrm{gg}^{-1}\right)$ of arsenic was found in fruity vegetables (okra) whereas the minimum concentration $\left(0.014 \mu \mathrm{gg}^{-1}\right)$ was also detected in vegetables (cauliflower).

Table 1: Permissible limits (FAO/WHO 1999) of the metals $\left(\mu \mathrm{gg}^{-1}\right)$

\begin{tabular}{|c|c|c|c|c|}
\hline Permissible & Cadmium & Lead & Arsenic & Mercury \\
\cline { 2 - 5 } Limits & $\mathbf{0 . 1}$ & $\mathbf{0 . 2}$ & $\mathbf{0 . 1}$ & $\mathbf{0 . 0 3}$ \\
\hline
\end{tabular}


Table 2: Concentration $\left(\mu \mathrm{gg}^{-1}\right)$ of toxic metals in leafy vegetables

\begin{tabular}{|l|l|l|l|l|l|l|}
\hline \multirow{2}{*}{ S \# } & \multirow{2}{*}{ Commodity } & \multirow{2}{*}{$\begin{array}{c}\text { No. of } \\
\text { samples }\end{array}$} & \multicolumn{4}{|c|}{ Average metal concentration $\left(\mu \mathbf{g g}^{-1}\right)$} \\
\cline { 4 - 7 } & & 10 & $\mathrm{Cd}$ & \multicolumn{1}{c|}{$\mathrm{Pb}$} & \multicolumn{1}{c|}{$\mathrm{As}$} & \multicolumn{1}{c|}{$\mathrm{Hg}$} \\
\hline 1 & Coriander & 10 & 0.084 & $0.150^{* *}$ & 0.031 & $0.001^{*}$ \\
& & & \pm 0.005 & \pm 0.0055 & \pm 0.0028 & \pm 0.00024 \\
\hline 2 & Fenugreek/ Methi & 10 & $0.090^{* *}$ & 0.059 & $0.065^{* *}$ & $0.020^{* *}$ \\
& & & \pm 0.0035 & \pm 0.0036 & \pm 0.0036 & \pm 0.0008 \\
\hline 3 & Spinach & 10 & 0.087 & $0.010^{*}$ & $0.016^{*}$ & 0.009 \\
& & & \pm 0.003 & \pm 0.0011 & \pm 0.0017 & \pm 0.00021 \\
\hline 4 & Mint & 10 & $0.071^{*}$ & 0.012 & 0.057 & 0.005 \\
& & & \pm 0.003 & \pm 0.0013 & \pm 0.003 & \pm 0.00022 \\
\hline
\end{tabular}

$\pm=$ Standard deviation

$*$ = Minimum concentration

$* *=$ Maximum concentration

Table 3: Concentration $\left(\mu \mathrm{gg}^{-1}\right)$ of toxic metals in root/ tuberous vegetables

\begin{tabular}{|c|c|c|c|c|c|c|}
\hline \multirow{2}{*}{$\begin{array}{l}\mathbf{S} \\
\#\end{array}$} & \multirow{2}{*}{ Commodity } & \multirow{2}{*}{$\begin{array}{c}\text { No. of } \\
\text { samples }\end{array}$} & \multicolumn{4}{|c|}{ Average metal Concentration $\left(\mu \mathrm{gg}^{-1}\right)$} \\
\hline & & & $\mathrm{Cd}$ & $\mathrm{Pb}$ & As & $\mathrm{Hg}$ \\
\hline 1 & Arum & 10 & $\begin{array}{l}0.086 * * \\
\pm 0.0037\end{array}$ & $\begin{array}{l}0.022 \\
\pm 0.002\end{array}$ & $\begin{array}{l}0.017 * \\
\pm 0.0024\end{array}$ & $\begin{array}{l}0.010 * * \\
\pm 0.00085\end{array}$ \\
\hline 2 & Onion & 10 & $\begin{array}{l}0.079 \\
\pm 0.0048\end{array}$ & $\begin{array}{l}0.006 \\
\pm 0.001\end{array}$ & $\begin{array}{l}0.023 \\
\pm 0.0024\end{array}$ & $\begin{array}{l}0.009 \\
\pm 0.00053\end{array}$ \\
\hline 3 & Potato & 10 & $\begin{array}{l}0.040^{*} \\
\pm 0.0031\end{array}$ & $\begin{array}{l}0.091 * * \\
\pm 0.0044\end{array}$ & $\begin{array}{l}0.025 \\
\pm 0.0022\end{array}$ & $\begin{array}{l}0.001 * \\
\pm 0.00010\end{array}$ \\
\hline 4 & Radish & 10 & $\begin{array}{l}0.045 \\
\pm 0.003\end{array}$ & $\begin{array}{l}0.043 \\
\pm 0.0026\end{array}$ & $\begin{array}{l}0.090 * * \\
\pm 0.0030\end{array}$ & $\begin{array}{l}0.005 \\
\pm 0.00022\end{array}$ \\
\hline 5 & Sugar beet & 10 & $\begin{array}{l}0.047 \\
\pm 0.0035\end{array}$ & $\begin{array}{l}0.001 * \\
\pm 0.0002\end{array}$ & $\begin{array}{l}0.038 \\
\pm 0.0027\end{array}$ & $\begin{array}{l}0.005 \\
\pm 0.00030\end{array}$ \\
\hline 6 & Turnip & 10 & $\begin{array}{l}0.050 \\
\pm 0.0033\end{array}$ & $\begin{array}{l}0.019 \\
\pm 0.0014\end{array}$ & $\begin{array}{l}0.081 \\
\pm 0.0051\end{array}$ & $\begin{array}{l}0.001 * \\
\pm 0.00016\end{array}$ \\
\hline
\end{tabular}

Table 4: Concentration $\left(\mu \mathrm{gg}^{-1}\right)$ of toxic metals in cucurbit vegetables

\begin{tabular}{|l|l|l|l|l|l|l|}
\hline S & \multirow{2}{*}{ Commodity } & \multirow{2}{*}{$\begin{array}{c}\text { No. of } \\
\text { samples }\end{array}$} & \multicolumn{4}{|c|}{ Average metal Concentration $\left(\mu_{g^{-1}}{ }^{-1}\right)$} \\
\cline { 4 - 7 } & & \multicolumn{1}{|c|}{$\mathrm{Cd}$} & \multicolumn{1}{c|}{$\mathrm{Pb}$} & \multicolumn{1}{c|}{$\mathrm{As}$} & $\mathrm{Hg}$ \\
\hline 1 & Bitter gourd & 10 & 0.016 & $0.018^{*}$ & $0.039^{*}$ & 0.0091 \\
& & & \pm 0.0020 & \pm 0.0017 & \pm 0.0025 & \pm 0.0005 \\
\hline 2 & Cucumber & 10 & $0.037^{* *}$ & $0.069^{* *}$ & 0.042 & $0.0056^{*}$ \\
& & & \pm 0.0039 & \pm 0.005 & \pm 0.0032 & \pm 0.0004 \\
\hline 3 & Indian & 10 & $0.002^{*}$ & 0.055 & $0.090^{* *}$ & $0.0110^{* *}$ \\
& Squash & & \pm 0.00047 & \pm 0.004 & \pm 0.0026 & \pm 0.00067 \\
\hline 4 & Pumpkin/ & 10 & 0.032 & 0.065 & 0.053 & 0.0100 \\
& Loki & & \pm 0.0032 & \pm 0.0067 & \pm 0.0042 & \pm 0.00075 \\
\hline
\end{tabular}


Table 5: Concentration $\left(\mu \mathrm{gg}^{-1}\right)$ of toxic metals in fruits vegetables

\begin{tabular}{|c|c|c|c|c|c|c|}
\hline \multirow{2}{*}{$\begin{array}{l}\mathbf{S} \\
\#\end{array}$} & \multirow{2}{*}{ Commodity } & \multirow{2}{*}{$\begin{array}{c}\text { No. of } \\
\text { samples }\end{array}$} & \multicolumn{4}{|c|}{ Average metal Concentration $\left(\mu \mathrm{gg}^{-1}\right)$} \\
\hline & & & $\mathrm{Cd}$ & $\mathrm{Pb}$ & As & $\mathrm{Hg}$ \\
\hline 1 & Brinjal & 10 & $\begin{array}{l}0.025 \\
\pm 0.0031 \\
\end{array}$ & $\begin{array}{l}0.036 \\
\pm 0.0042 \\
\end{array}$ & $\begin{array}{l}0.035 \\
\pm 0.0039 \\
\end{array}$ & $\begin{array}{l}0.007 \\
\pm 0.00056 \\
\end{array}$ \\
\hline 2 & Cabbage & 10 & $\begin{array}{l}0.049 \\
\pm 0.0061\end{array}$ & $\begin{array}{l}0.084 \\
\pm 0.0061 \\
\end{array}$ & $\begin{array}{l}0.091 * * \\
\pm 0.0106 \\
\end{array}$ & $\begin{array}{l}0.003^{*} \\
\pm 0.00042 \\
\end{array}$ \\
\hline 3 & Cauliflower & 10 & $\begin{array}{l}0.075 * * \\
\pm 0.0064\end{array}$ & $\begin{array}{l}0.088 \\
\pm 0.0105\end{array}$ & $\begin{array}{l}0.014^{*} \\
\pm 0.0024\end{array}$ & $\begin{array}{l}0.009 \\
\pm 0.00103\end{array}$ \\
\hline 4 & Chilies & 10 & $\begin{array}{l}0.018 \\
\pm 0.0034\end{array}$ & $\begin{array}{l}0.041 \\
\pm 0.0054\end{array}$ & $\begin{array}{l}0.053 \\
\pm 0.0068\end{array}$ & $\begin{array}{l}0.010^{* *} \\
\pm 0.00113\end{array}$ \\
\hline 5 & $\begin{array}{l}\text { French } \\
\text { beans }\end{array}$ & 10 & $\begin{array}{l}0.029 \\
\pm 0.0037 \\
\end{array}$ & $\begin{array}{l}0.089 * * \\
\pm 0.0108 \\
\end{array}$ & $\begin{array}{l}0.080 \\
\pm 0.0093 \\
\end{array}$ & $\begin{array}{l}0.008 \\
\pm 0.00102 \\
\end{array}$ \\
\hline 6 & Okra & 10 & $\begin{array}{l}0.013^{*} \\
\pm 0.0024 \\
\end{array}$ & $\begin{array}{l}0.064 \\
\pm 0.0062 \\
\end{array}$ & $\begin{array}{l}0.083 \\
\pm 0.0073 \\
\end{array}$ & $\begin{array}{l}0.009 \\
\pm 0.00100 \\
\end{array}$ \\
\hline 7 & Tomato & 10 & $\begin{array}{l}0.071 \\
\pm 0.0086 \\
\end{array}$ & $\begin{array}{l}0.009 * \\
\pm 0.0017 \\
\end{array}$ & $\begin{array}{l}0.025 \\
\pm 0.0038\end{array}$ & $\begin{array}{l}0.005 \\
\pm 0.00072 \\
\end{array}$ \\
\hline
\end{tabular}

\section{CONCLUSION AND RECOMMENDATION}

Present study shows that the concentration of cadmium, lead and arsenic were comparatively high in leafy vegetables. The reason for this trend is because of high translocation and transpiration rate of leafy vegetables in which transfer of metals from root to stem and ultimately to fruit is longer which results in lower accumulation other than leafy vegetables. Objective of this study was to monitor the levels of toxic heavy metals $(\mathrm{Cd}, \mathrm{Pb}, \mathrm{As}$ and $\mathrm{Hg})$ in different vegetables grown in Sindh. Results revealed that the studied vegetables grown in Sindh, Pakistan, contain only the trace amount of these toxic metals. The concentrations found were within the permissible limits given by W.H.O/ F.A.O (1999) and safe in consumption point of view.

\section{ACKNOLEDGMENT}

We express our sincere gratitude to honorable Chairman, Pakistan Agricultural Research Council (PARC), Member (Crop Science), PARC and Executive Director, ALP-Project for their kind approval of this project.

\section{REFERENCE}

1. Ahmed S, Waheed S, Mannan A, Fatima I \& Qureshi I H 1994. Evaluation of trace elements in wheat and wheat by-products. J.AOAC. 77: 11.

2. Bhutto M A, Zahida P, Riazuddin, Sajid I, Mubarik A, \& Sahar N, 2009. Monitoring of heavy and essential trace metals in wheat procured form various countries. Int. J. Biol. Biotech., 6(4): 247.

3. FAO/WHO 1999. Expert Committee on Food Additives, Summary and conclusions, 53rd Meeting, Rome. 
4. Ghandi Z, 2000. Permission threshold values of some pollutants in production of free pollution vegetables. Chemical Abst. 461.

5. Government of Pakistan, Economic Survey of Pakistan. Economic Advisory Wing, Finance Division Islamabad, 2 (2008-09) 17.

6. Irshad A S, and Jan M R, 1997. Physico-chemical studies of polluants. Prco. NSMTCC 97 on Environmental Pollution. Feb.24-26. Islamabad, Pakistan

7. Itanna F, 2002. Metals in leafy vegetables grown in Addis Ababa and toxicological implications. Ethiopian. J. Health Dev, 6: 295.

8. Jarup L, 2003. Hazards of heavy metal contamination. Br. Med. Bull. 68: 167.

9. Nergus Y, Ahmed S I, and Sharif M, 2005. Impact of contaminated vegetables, fruits and fodders on human health by Malir river farms Karachi. J. Chem. Soc. Pak. 6: 561.

10. Perveen Z, Khuhro M I, and Rafiq N, 2003. Market basket survey for lead, cadmium, copper, chromium and zinc in fruits and vegetables. Bull. Environ. Contam. Toxicol. 71: 1260.

11. Robert W, \& Glandys Lacroix M A 1987. Total arsenic in food after wet and dry digestion and co-precipitate with ammonium pyrollidine dithiocarbamate using Graphite Furnace Atomic Absorption Spectrophotometer. J. A.O.A.C. 70(5): 866.

12. Sathawara, N G, Parikh D J, \& Agarwal Y K, 2004. Essentail heavy metals in environmental samples from western India. Bul. Environ. Contam. Toxicol., 73: 756.

13. Sharma R K, Agrawal M, and Marshal F M, 2009. Heavy metals in vegetables collected from production and market sites of a tropical urban area of India. Food Chem Toxicol. 47(3): 583.

14. Viqar N, and Ahmed R, 1992. Decomposition of Vegetables for determination of Zn, Cd, $\mathrm{Pb}$ and $\mathrm{Cu}$ by stripping voltammerty. Mikrochim. 106: 137.

15. Wiermans D, and Ven Goor B G, 1986. Cadmium, lead, mercury and arsenic concentration in crops and corresponding soil in Netherlands. J Agric. Food Chem. 34: 1067.

16. Yousufzai A H K, Hashmi D R, Ahmed F, and Durrani K, 2001. Heavy metal accumulation in roadside vegetation of urban areas of Karachi. Pak. J. Sci. Ind. Res. 44: 29.

17. Zahir E, Imran I, and Mohyuddin S, 2009. Market Basket Survey of selected metals in fruits from Krachi city (Pakistan). J.basic appl. Sci. 5(2): 47. 